\title{
Effects of 12-0-tetradecanoylphorbol-13-acetate in combination with gemcitabine on Panc-1 pancreatic cancer cells cultured in vitro or Panc-1 tumors grown in immunodeficient mice
}

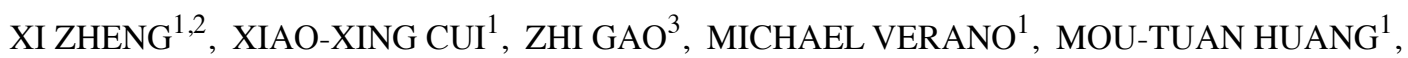 \\ YUE LIU ${ }^{1}$, ARNOLD B. RABSON ${ }^{4}$ and ALLAN H. CONNEY ${ }^{1,2,5}$
}

${ }^{1}$ Susan Lehman Cullman Laboratory for Cancer Research, Department of Chemical Biology, Ernest Mario School of Pharmacy, Rutgers, The State University of New Jersey, Piscataway, NJ 08854, USA;

${ }^{2}$ Allan H. Conney Laboratory for Anticancer Research, College of Light Industrial and Chemical Engineering, Guangdong University of Technology, Guangzhou 510006; ${ }^{3}$ The Second Affiliated Hospital of

Chongqing Medical University, Chongqing 400010, P.R. China; ${ }^{4}$ Child Health Institute of New Jersey, UMDNJ-RWJMS, New Brunswick, NJ 08901; ${ }^{5}$ Cancer Institute of New Jersey, New Brunswick, NJ 08903, USA

Received June 27, 2012; Accepted August 17, 2012

DOI: 10.3892/ijo.2012.1651

\begin{abstract}
In the present study, the effects of 12-O-tetradecanoylphorbol-13-acetate (TPA) alone or in combination with gemcitabine on the growth of Panc-1 pancreatic cancer cells cultured in vitro or grown in $\mathrm{NCr}$ immunodeficient nude mice were investigated. Combinations of TPA and gemcitabine synergistically inhibited the growth and induced apoptosis in Panc-1 cells. The combination of TPA $(0.16 \mathrm{nM})$ and gemcitabine $(0.5 \mu \mathrm{M})$ induced a marked increase in phosphorylated c-Jun NH2-terminal kinase (JNK) in the Panc-1 cells. In animal experiments, $\mathrm{NCr}$ nude mice with established Panc-1 tumors received daily intraperitoneal (i.p.) injections of TPA ( $50 \mathrm{ng} / \mathrm{g}$ body weight/day) or gemcitabine $(0.5 \mu \mathrm{g} / \mathrm{g}$ body weight/ day) alone or in combination for 26 days. Treatment with daily i.p. injections of low doses of TPA or gemcitabine alone had a modest inhibitory effect on the growth of the tumors. However, the combination of low doses of TPA and gemcitabine more potently inhibited the growth of Panc-1 tumors than either agent used individually. Treatment with TPA or gemcitabine alone or in combination did not affect the body weight of the animals. Clinical trials with TPA alone or in combination with gemcitabine on patients with pancreatic cancer are warranted in order to confirm our results.
\end{abstract}

Correspondence to: Dr Xi Zheng or Dr Allan H. Conney, Susan Lehman Cullman Laboratory for Cancer Research, Department of Chemical Biology, Ernest Mario School of Pharmacy, Rutgers, The State University of New Jersey, 164 Frelinghuysen Road, Piscataway, NJ 08854, USA

E-mail: xizheng@pharmacy.rutgers.edu

E-mail: aconney@pharmacy.rutgers.edu

Key words: phorbol ester, gemcitabine, chemotherapy, c-Jun NH2terminal kinase, pancreatic cancer

\section{Introduction}

Pancreatic cancer is one of the most lethal human malignancies (1). It was estimated that this disease caused more than 37,000 deaths in the United States in 2011 (2). Despite efforts in the past 50 years, conventional treatment approaches, such as surgery, radiation, chemotherapy, or combinations of these, have had little impact on the course of this aggressive neoplasm. Five-year survival rates remain at approximately $5 \%$ and a median survival of $<6$ months has remained unchanged for the last three decades (3-5). Surgical resection is still the only curative therapy, although in $80 \%$ of patients the tumor is already unresectable at diagnosis due to metastasis or local invasion (6). Even in 15 to $20 \%$ of patients undergoing potentially curative resection, the five-year survival is only $20 \%$ $(6,7)$. Almost $100 \%$ of patients with pancreatic cancer develop metastases and succumb to the disease due to the debilitating metabolic effects of the unrestrained growth. Therefore, it is imperative to develop novel anticancer agents and effective combination therapies for the treatment of pancreatic cancer.

Gemcitabine (2,2-difluorodeoxycytidine) is a deoxycytidine-analog antimetabolite with broad activity against a variety of solid tumors and lymphoid malignancies (8). Gemcitabine is an important anticancer drug that has been approved for the treatment of non-small cell lung, pancreatic, bladder and breast cancers (9). This drug was approved as the standard of care in patients with pancreatic cancer over a decade ago (10). Treatment with gemcitabine improves clinical benefit responses, such as pain reduction, improvement in Karnofsky performance status and increase in body weight. However, the benefit of single-agent gemcitabine treatment in advanced and metastatic pancreatic cancer is inadequate. Combinations of gemcitabine and novel anticancer agents that target critical survival pathways in pancreatic cancer cells may have synergistic effects on growth inhibition and apoptosis and improve the therapeutic efficacy of gemcitabine. 
The phorbol ester, 12-O-tetradecanoylphorbol-13acetate (TPA) is a major active constituent of the seed oil of Croton tiglium L., a leafy shrub of the Euphorbiaceae family that is native to Southeastern Asia. In a preliminary study, our laboratory together with colleagues in China demonstrated pharmacological activity for intravenously administered TPA for the treatment of seriously ill myeloid leukemia patients refractory to other therapy (11). The results obtained in this study and data from a phase I trial with TPA at the Cancer Institute of New Jersey $(12,13)$ indicated an acceptable toxicity profile. The study in the Cancer Institute of New Jersey using a different dosage than that used in China failed to find any positive effects of TPA on myeloid leukemia patients $(12,13)$. In additional studies, we found that a low clinically achievable concentration of TPA $(0.16 \mathrm{nM})$ in combination with all-trans retinoic acid (ATRA), 1 $\alpha, 25$-dihydroxyvitamin $\mathrm{D}_{3}$, sodium butyrate, or an NF- $\kappa \mathrm{B}$ inhibitor (E)3-[(4-methylphenyl)sulfonyl]-2-propenenitrile (BAY 11-7082) synergistically inhibited the growth and stimulated the differentiation of cultured HL-60 myeloid leukemia cells $(14,15)$. Studies from our laboratory and from other investigators have shown that TPA inhibits growth and induces apoptosis in cultured pancreatic cancer cells (16-19). In a previous study, we also found that TPA alone or in combination with ATRA inhibited the growth of Panc-1 and BxPC-3 pancreatic tumor xenografts in immunodeficient mice (16).

In the present study, we determined the effects of TPA alone or in combination with gemcitabine on the growth and apoptosis of Panc-1 pancreatic cancer cells cultured in vitro or Panc-1 tumors grown in immunodeficient mice. We also determined the effect of these drugs alone or in combination on the activation of c-Jun NH2-terminal kinase (JNK). We found that TPA in combination with gemcitabine more potently inhibited the growth and induced apoptosis in cultured Panc- 1 cells than either agent alone. We also found that the combination of TPA and gemcitabine had a stronger inhibitory effect on the growth of Panc-1 tumors in immunodeficient mice than either agent alone.

\section{Materials and methods}

Cell culture and reagents. Panc-1 cells were obtained from Dr Pamela Crowell (Indiana University-Purdue University Indianapolis, Indianapolis, IN). TPA was obtained from Alexis Co. (San Diego, CA). Gemcitabine was provided by the Eli Lilly Co. (Indianapolis, IN). Propylene glycol, polysorbate 80, benzyl alcohol, ethanol and DMSO were purchased from Sigma (St. Louis, MO). Matrigel was obtained from BD Biosciences (Bedford, MA). Dulbecco's modified Eagle's medium (DMEM) tissue culture medium, penicillin-streptomycin, L-glutamine and fetal bovine serum (FBS) were from Gibco (Grand Island, NY). Panc-1 cells were maintained in DMEM culture medium containing 10\% FBS that was supplemented with penicillin $(100 \mathrm{U} / \mathrm{ml})$-streptomycin $(100 \mu \mathrm{g} / \mathrm{ml})$ and L-glutamine $(300 \mu \mathrm{g} / \mathrm{ml})$. Cultured cells were grown at $37^{\circ} \mathrm{C}$ in a humidified atmosphere of $5 \% \mathrm{CO}_{2}$ and were passaged twice a week. Panc-1 cells were initially seeded at a density of $0.2 \times 10^{5}$ cells $/ \mathrm{ml}$ in $35-\mathrm{mm}$ tissue culture dishes $(2 \mathrm{ml} / \mathrm{dish}$ ) for the proliferation and apoptosis assays, and seeded at a density of $1 \times 10^{5}$ cells $/ \mathrm{ml}$ of medium in $100 \mathrm{~mm}$ culture dishes $(10 \mathrm{ml} /$ dish) for the western blot analysis. TPA and gemcitabine were dissolved in DMSO, and the final concentration of DMSO in all experiments was $0.2 \%$.

Determination of the number of viable cells. The number of viable cells after each treatment was determined using a hemacytometer under a light microscope (Nikon Optiphot, Hyogo, Japan). Cell viability was determined by the trypan blue exclusion assay, which was carried out by mixing $80 \mu \mathrm{l}$ of cell suspension and $20 \mu \mathrm{l}$ of $0.4 \%$ trypan blue solution for $2 \mathrm{~min}$. Blue cells were counted as dead cells and the cells that did not absorb dye were counted as live cells.

Morphological assessment of apoptotic cells. Apoptosis was determined by morphological assessment in the cells stained with propidium iodide $(20,21)$. Briefly, cytospin slides were prepared after each experiment and the cells were fixed with acetone/methanol (1:1) for $10 \mathrm{~min}$ at room temperature, followed by $10 \mathrm{~min}$ with propidium iodide staining $(1 \mu \mathrm{g} / \mathrm{ml}$ in PBS) and analyzed using a fluorescence microscope (Nikon Eclipse TE200; Nikon, Tokyo, Japan). Apoptotic cells were identified by classical morphological features including nuclear condensation, cell shrinkage and the formation of apoptotic bodies $(20,21)$. At least 200 cells were counted in each sample and the percentage of apoptotic cells was presented.

Western blot analysis. After treatment, Panc-1 cells were washed with ice-cold PBS and lysed with $800 \mu 1$ of lysis buffer (10 mM Tris- $\mathrm{HCl}, \mathrm{pH} 7.4,50 \mathrm{mM}$ sodium chloride, $30 \mathrm{mM}$ sodium pyrophosphate, $50 \mathrm{mM}$ sodium fluoride, $100 \mu \mathrm{M}$ sodium orthovandate, $2 \mathrm{mM}$ iodoacetic acid, $5 \mathrm{mM} \mathrm{ZnCl}_{2}$, $1 \mathrm{mM}$ phenylmethylsulfonyl fluoride and $0.5 \%$ Triton X-100). The homogenates were centrifuged at $12,000 \mathrm{x} \mathrm{g}$ for $15 \mathrm{~min}$ at $4^{\circ} \mathrm{C}$. The protein concentration of whole cell lysates was determined with a Bio-Rad protein assay kit (Bio-Rad, Hercules, CA). Equal amounts $(20 \mu \mathrm{g})$ of protein were then resolved on a $10 \%$ Criterion precast gel (Bio-Rad) and transferred onto a PVDF membrane using a semi-dry transfer system. The membrane was then probed with anti-phosphorylated JNK primary antibodies (Cell Signaling Technology, Beverly, MA). After hybridization with primary antibody, the membrane was washed with Tris-buffered saline three times, then incubated with horseradish peroxidase-conjugated secondary antibody (Santa Cruz Biotechnology, Santa Cruz, CA) and washed with Tris-buffered saline three times. Final detection was performed with enhanced chemiluminescent reagents. The extent of protein loading was determined by blotting for $\beta$-actin. The membrane was incubated in stripping buffer $(100 \mathrm{mM} \beta$-mercaptoethanol, 2\% SDS, and $62.5 \mathrm{mM}$ Tris- $\mathrm{HCl}$ at $\mathrm{pH} 6.7$ ) at $50^{\circ} \mathrm{C}$ for $30 \mathrm{~min}$ with occasional agitation before incubating in blocking buffer and re-probing using anti- $\beta$ actin antibody (Santa Cruz Biotechnology).

Panc-1 tumor xenografts in $\mathrm{NCr}$ nude mice. Female $\mathrm{NCr}$ nude mice (6-7 weeks old) were obtained from Taconic Farms Inc. (Germantown, NY). The animals were housed in sterile filter-capped microisolator cages and provided with sterilized food and water. For subcutaneous tumor xenografts, Panc-1 pancreatic cancer cells $\left(2 \times 10^{6}\right.$ cells $/ 0.1 \mathrm{ml} /$ mouse) suspended in 50\% Matrigel (Collaborative Research, Bedford, MA) in 
A

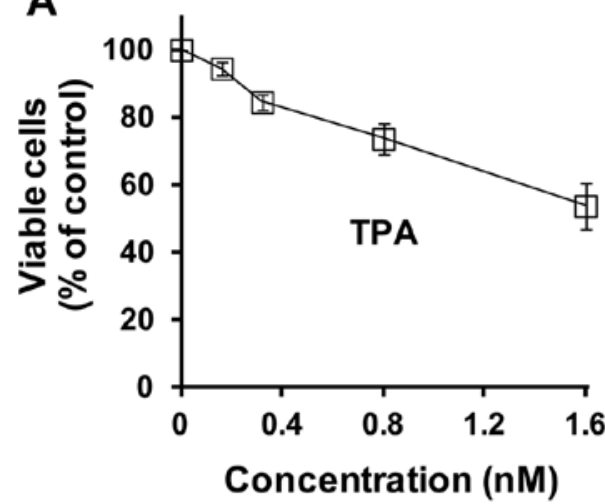

C

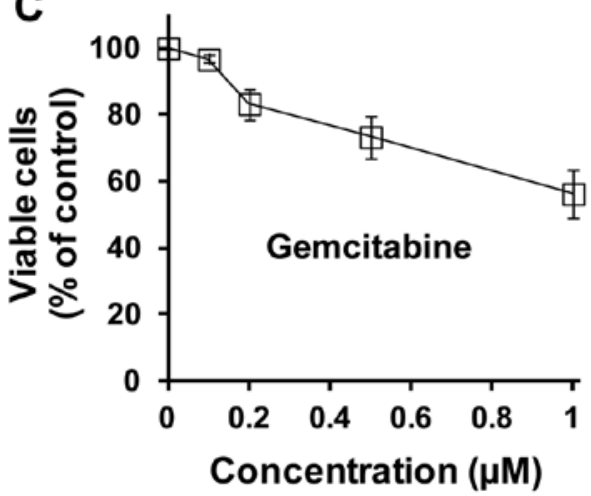

B
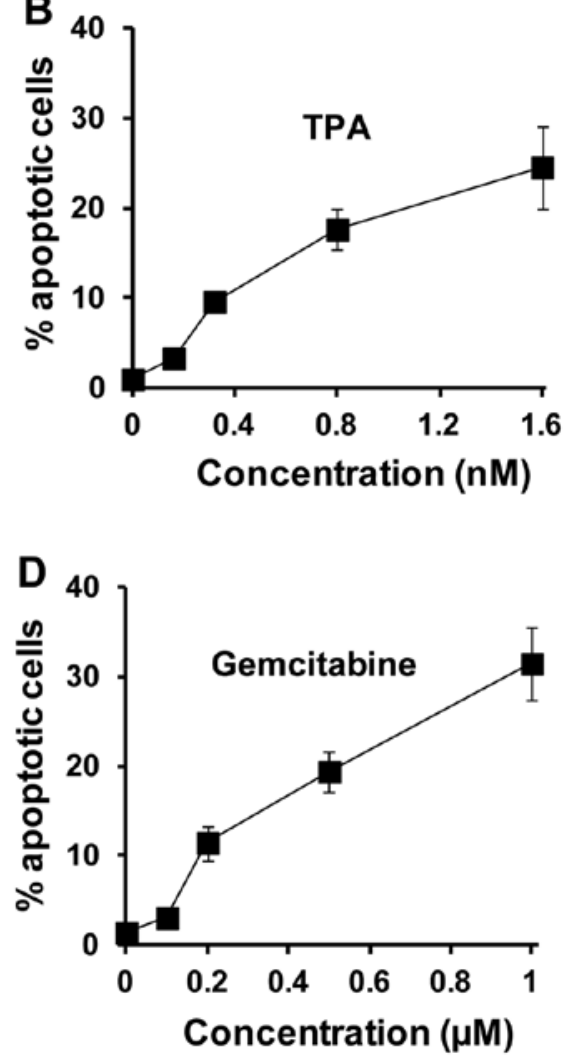

Figure 1. Effects of TPA or gemcitabine on growth and apoptosis of Panc-1 cells. Panc-1 cells were seeded at a density of $0.2 \times 10^{5}$ cells/ml of medium and incubated for $24 \mathrm{~h}$. The cells were then treated with TPA $(0.16$ to $1.6 \mathrm{nM})$ or gemcitabine $(0.1$ to $1.0 \mu \mathrm{M})$ alone for $96 \mathrm{~h}$. The number of viable cells was determined by a trypan blue exclusion assay (16). Apoptotic cells were determined by morphological assessment (21). Each value is the mean $\pm \mathrm{SE}$ from at least three experiments.

DMEM medium were injected subcutaneously into the right flank of the mice (22). When the tumors reached a moderate size (0.6-1.0 cm wide and 0.6-1.0 cm long), the mice received daily intraperitoneal (i.p.) injections with TPA (50 ng/g body weight/ day), gemcitabine $(0.5 \mu \mathrm{g} / \mathrm{g}$ body weight/day) or a combination of TPA $(50 \mathrm{ng} / \mathrm{g} /$ day $)$ and gemcitabine $(0.5 \mu \mathrm{g} / \mathrm{g} /$ day $)$ for 26 days. Each group consisted of eight animals. In all the experiments, animals in the different experimental groups received the same amount of the vehicle ( $5 \mu \mathrm{l} / \mathrm{g}$ body weight) which consisted of propylene glycol, polysorbate 80 , benzyl alcohol, ethanol and water (40:0.5:1:10:48.5) (21). Tumor size (length $\mathrm{x}$ width) and body weight were measured three times a week. The animal experiments were carried out under an Institutional Animal Care and Use Committee (IACUC)-approved protocol.

Statistical analyses. The potential synergistic effect of TPA and gemcitabine was assessed by the isobole method (23), using the equation $\mathrm{Ac} / \mathrm{Ae}+\mathrm{Bc} / \mathrm{Be}=$ combination index $(\mathrm{CI})$. $\mathrm{Ac}$ and $\mathrm{Bc}$ represent the concentration of drug $\mathrm{A}$ and $\mathrm{B}$ used in the combination, and $\mathrm{Ae}$ and $\mathrm{Be}$ represent the concentration of drug $A$ and $B$ that produced the same magnitude of effect when administered alone. If the $\mathrm{CI}$ is $<1$, then the drugs are considered to act synergistically. If the CI is $>1$ or $=1$, then the drugs are considered to act in an antagonistic or additive manner, respectively. The analysis of variance (ANOVA) model with Tukey-Kramer adjustment (24) was used for the comparison of tumor size and body weight among the different treatment groups at the end of the treatment period.

\section{Results}

Effects of TPA and gemcitabine on growth and apoptosis of Panc-1 pancreatic cancer cells. The in vitro effects of TPA and gemcitabine alone or in combination on the growth and apoptosis of pancreatic cancer cells were determined using the Panc-1 human pancreatic cancer cell line. In our experiments, Panc-1 cells were treated with TPA or gemcitabine alone or in combination for $96 \mathrm{~h}$. As shown in Fig. 1, the treatment of Panc-1 cells with TPA (0.16-1.6 nM) or gemcitabine (0.1-1.0 $\mu \mathrm{M})$ alone resulted in a concentration-dependent decrease in the number of viable cells. Combinations of TPA and gemcitabine more potently inhibited the growth of Panc-1 cells than either agent alone (Table I). The CI for $\mathrm{IC}_{50}$ was calculated as 0.83 , indicating the synergistic effect of TPA and gemcitabine in combination in the inhibition of the growth of cultured Panc-1 cells. Treatment with TPA (0.16-1.6 nM) or gemcitabine (0.1-1.0 $\mu \mathrm{M})$ resulted in $3-25$ and $3-32 \%$ apoptosis, respectively (Fig. 1). Various combinations of TPA and gemcitabine at different concentrations all had stronger effects on the stimulation of apoptosis than either agent alone (Table I). The CI for 50\% apoptosis was calculated as 0.69 . Our results indicated that a combination of TPA and gemcitabine had synergistic effects on growth inhibition and apoptosis stimulation in Panc-1 cells.

Activation of JNK in Panc-1 cells treated with TPA or gemcitabine alone or in combination. The effect of TPA and 
Table I. Effects of TPA and/or gemcitabine on the growth and apoptosis of Panc-1 cells.

\begin{tabular}{lcc}
\hline Treatment & $\begin{array}{c}\text { Viable cells } \\
(\% \text { of control })\end{array}$ & $\begin{array}{c}\text { Apoptosis } \\
(\% \text { of cells })\end{array}$ \\
\hline Control & 100 & $1.1 \pm 0.1$ \\
TPA $(0.16 \mathrm{nM})$ & $94.5 \pm 1.9$ & $3.3 \pm 0.5$ \\
Gemcitabine $(0.1 \mu \mathrm{M})$ & $96.7 \pm 1.2$ & $3.0 \pm 1.1$ \\
TPA $(0.16 \mathrm{nM})$ & $77.5 \pm 3.7$ & $12.8 \pm 1.7$ \\
+ gemcitabine $(0.1 \mu \mathrm{M})$ & & \\
TPA $(0.80 \mathrm{nM})$ & $73.7 \pm 4.4$ & $17.6 \pm 2.3$ \\
Gemcitabine $(0.5 \mu \mathrm{M})$ & $73.3 \pm 6.5$ & $19.4 \pm 2.3$ \\
TPA $(0.80 \mathrm{nM})$ & $31.6 \pm 3.2$ & $50.7 \pm 3.3$ \\
+ gemcitabine $(0.5 \mu \mathrm{M})$ & & \\
\hline
\end{tabular}

Panc- 1 cells were seeded at a density of $0.2 \times 10^{5}$ cells $/ \mathrm{ml}$ of medium and incubated for $24 \mathrm{~h}$. The cells were then treated with TPA $(0.16$ or $0.80 \mathrm{nM})$ or gemcitabine $(0.1$ or $0.5 \mu \mathrm{M})$ alone or in combination for $96 \mathrm{~h}$. The number of viable cells was determined by a trypan blue exclusion assay (16). Apoptotic cells were determined by morphological assessment (21). Each value is the mean \pm SE from three experiments.

gemcitabine on activation of JNK was determined by western blot analysis using an anti-phosphorylated JNK antibody that detects active, phosphorylated JNK (25). Panc-1 cells were treated with TPA $(0.8 \mathrm{nM})$ or gemcitabine $(0.5 \mu \mathrm{M})$ alone or in combination for $2 \mathrm{~h}$ and analyzed by western blot analysis. The treatment of Panc-1 cells with TPA $(0.8 \mathrm{nM})$ resulted in a significant increase in the level of phosphorylated JNK, while gemcitabine alone at $0.5 \mu \mathrm{M}$ caused a slight increase in the level of phosphorylated JNK (Fig. 2). Treatment of the cells with a combination of TPA $(0.8 \mathrm{nM})$ and gemcitabine $(0.5 \mu \mathrm{M})$ caused a further increase in the level of phosphorylated JNK when compared to either agent alone (Fig. 2).

Effects of a JNK inhibitor on apoptosis in Panc-1 cells induced by TPA or gemcitabine alone or in combination. To further investigate whether the activation of JNK is required for apoptosis in Panc-1 cells treated with TPA or gemcitabine alone or in combination, we determined the effect of a selective JNK inhibitor (SP600125, Sigma) on apoptosis in these cells. In these experiments, Panc-1 cells were seeded at a density of $0.2 \times 10^{5}$ cells $/ \mathrm{ml}$ of culture medium. The cells were treated with TPA $(0.8 \mathrm{nM})$ or gemcitabine $(0.5 \mu \mathrm{M})$ alone or in combination in the presence or absence of SP600125 $(10 \mu \mathrm{M})$ for $96 \mathrm{~h}$. Apoptotic cells were determined by morphological assessment. As shown in Fig. 3, the addition of SP600125 alone had a modest effect on apoptosis in Panc-1 cells. Treatment with SP600125 decreased apoptosis in the Panc-1 cells induced by TPA alone or in combination with gemcitabine (Fig. 3). Our results suggest that apoptosis in Panc-1 cells treated with TPA in combination with gemcitabine is at least partially mediated by the activation of JNK. Since SP600125 only partially abrogated the effect of TPA and gemcitabine on apoptosis, other factors may also be involved.

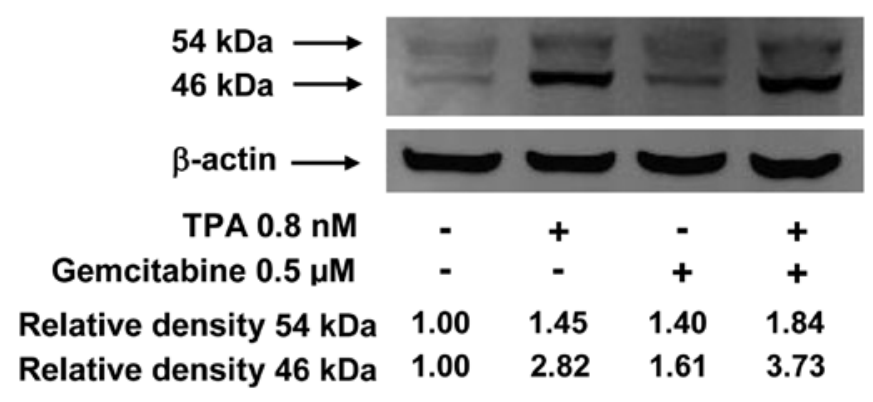

Figure 2. Effects of TPA or gemcitabine alone or in combination on the activation of JNK. Panc-1 cells were seeded at a density of $1 \times 10^{5}$ cells $/ \mathrm{ml}$ of medium and incubated for $24 \mathrm{~h}$. The cells were then treated with TPA $(0.8 \mathrm{nM})$ or gemcitabine $(0.5 \mu \mathrm{M})$ alone or in combination for $2 \mathrm{~h}$. Activated JNK was determined by the western blot analysis with an anti-phosphorylated-JNK antibody (\#9251, Cell Signaling Technology). The intensity of the phosphorylated JNK band relative to that of $\beta$-actin was determined and expressed as relative density.

Inhibitory effect of TPA or gemcitabine alone or in combination on the growth of Panc-1 tumor xenografts in $\mathrm{NCr}$ nude mice. Male NCr nude mice with subcutaneous Panc-1 tumors were treated with i.p. injections of TPA or gemcitabine alone or in combination once a day as described in Fig. 4. As shown in Fig. 4A, tumor growth was observed in the vehicle-treated control group. Treatment with i.p. injections of low concentrations of TPA or gemcitabine had a modest inhibitory effect on the growth of the tumors (Fig. 4A). The combination of low concentrations of TPA and gemcitabine more potently inhibited the growth of Panc-1 tumors than either agent used individually (Fig. 4A). Statistical analysis using ANOVA with the Tukey-Kramer multiple comparison test showed that the difference in the percentage of initial tumor size at the end of the experiment between the control group and the combination group was statistically significant $(\mathrm{p}<0.001)$, and that the differences between the TPA-treated group and the combination group $(p<0.01)$ or between the gemcitabine-treated group and the combination group were also statistically significant $(\mathrm{p}<0.05)$. As shown in Fig. 4B, treatment with TPA or gemcitabine alone or in combination did not affect the body weight of the animals. Statistical analysis using ANOVA with the Tukey-Kramer multiple comparison test showed that the difference in the percentage of initial body weight between any two groups was not statistically significant $(p>0.05)$.

\section{Discussion}

In the present study, we demonstrate that TPA in combination with gemcitabine synergistically inhibits the growth and stimulates apoptosis in cultured Panc-1 human pancreatic cancer cells. We also show that a combination of low concentrations of TPA and gemcitabine more potently inhibits the growth of Panc-1 tumors than either agent used individually. To the best of our knowledge, this is the first study indicating the synergistic effect of TPA and gemcitabine on growth and apoptosis in human pancreatic cancer cells.

TPA is an irritant and inflammatory agent that has been used in previous studies as a tumor promoter (usual dose $=5-16 \mathrm{nmol}$ twice a week) on the skin of mice previously initiated with 7,12-dimethylbenz[a]anthracene or other polycyclic aromatic 


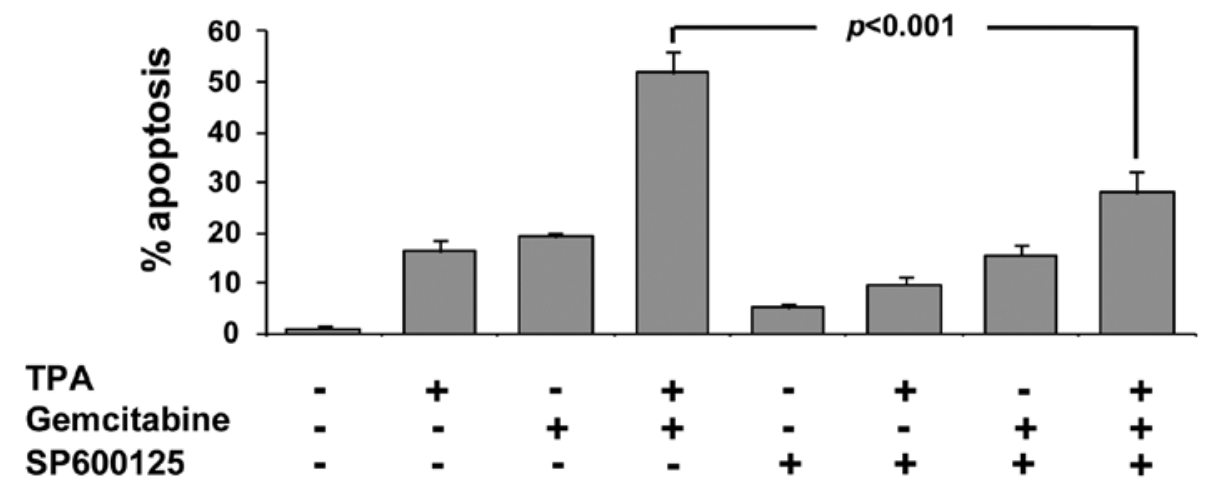

Figure 3. Effect of a JNK inhibitor (SP600125) on apoptosis in Panc-1 cells treated with TPA or gemcitabine alone or in combination. Panc-1 cells were seeded at a density of $0.2 \times 10^{5}$ cells $/ \mathrm{ml}$ of medium and incubated for $24 \mathrm{~h}$. The cells were then treated with TPA $(0.8 \mathrm{nM})$ or gemcitabine $(0.5 \mu \mathrm{M})$ alone or in combination in the presence or absence of SP600125 $(10 \mu \mathrm{M})$ for $96 \mathrm{~h}$. Apoptotic cells were determined by morphological assessment (21). Each value is the mean $\pm \mathrm{SE}$ of three experiments.

A

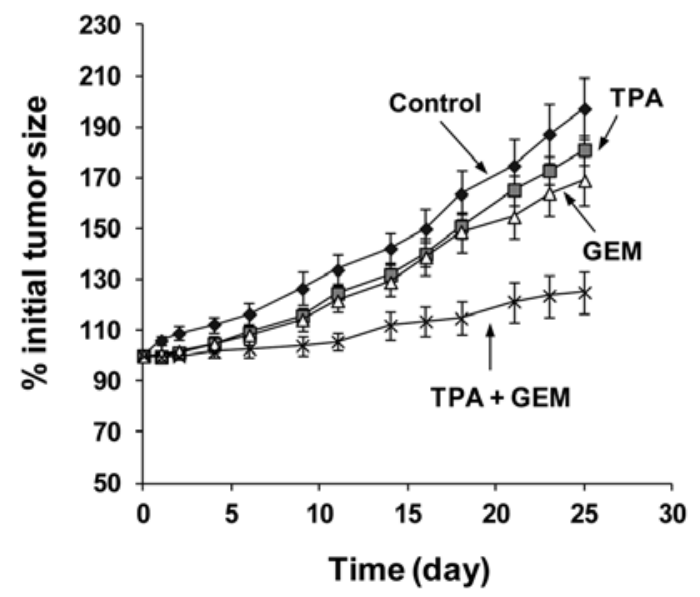

B

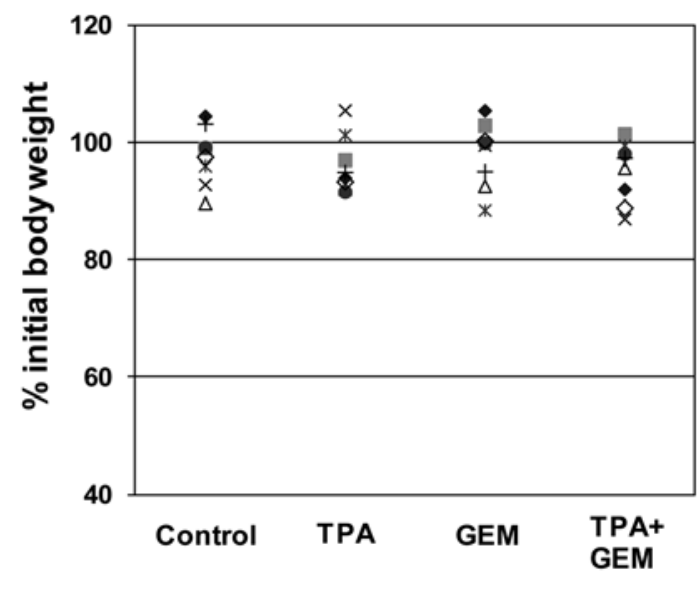

Figure 4. Effects of TPA or gemcitabine alone or in combination on the growth of (A) Panc-1 pancreatic tumors and (B) body weight of NCr nude mice. Male NCr nude mice were injected subcutaneously with Panc-1 cells in 50\% Matrigel (2.0x10 cells $/ 0.1 \mathrm{ml})$ suspended in DMEM medium. After four to six weeks, mice with Panc-1 tumors (0.6-1.0 cm wide and 0.6-1.0 cm long) were treated with daily i.p. injections of TPA (50 ng/g body weight/day) or gemcitabine $\left(0.5 \mu \mathrm{g} / \mathrm{g}\right.$ body weight/day) alone or in combination for 26 days. (A) Tumor size (length $\mathrm{x}$ width; $\left.\mathrm{cm}^{2}\right)$ was measured and expressed as the percentage of initial tumor size. Each value is the mean \pm SE from eight animals. (B) Body weight was determined and expressed as the percentage of initial body weight. Data from individual mice is shown.

hydrocarbons $(26,27)$. In contrast to the irritant effects of TPA at high concentrations on mouse skin, at a 10,000-fold lower concentration TPA is a potent stimulator of differentiation of cultured myeloid leukemia cells (28-30). Previous studies from our laboratory have demonstrated that TPA at clinically achievable concentrations inhibits the growth of cultured human prostate and pancreatic cancer cells $(16,21)$. The peak blood concentrations of TPA \pm SD in several patients who received an intravenous infusion of TPA $\left(0.125 \mathrm{mg} / \mathrm{m}^{2}\right)$ was $1.75 \pm 0.55 \mathrm{ng} / \mathrm{ml}$ and ranged between 0.3 and $5.2 \mathrm{ng} / \mathrm{ml}(13,31)$. The concentrations of TPA used to obtain a synergistic effect in the present study $(0.1-1 \mathrm{ng} / \mathrm{ml} ; 0.16-1.6 \mathrm{nM})$ are clinically achievable $(13,31)$.

Gemcitabine is the standard first-line chemotherapeutic agent for the treatment of advanced pancreatic cancer. The majority of pancreatic cancer patients treated with gemcitabine do not have an objective response to treatment and only a minority obtain stabilization of disease or a partial response $(9,32)$. Due to the inadequate benefit and significant toxic side-effects of gemcitabine as a single-agent $(9,32)$, efforts have been devoted to developing effective combinations of gemcitabine with other anticancer agents (33). However, the combination of other chemotherapeutic agents with gemcitabine has not resulted in a meaningful improvement in survival (34-38). Combinations of gemcitabine and novel anticancer agents that target critical survival pathways in pancreatic cancer cells may have synergistic effects on growth inhibition and apoptosis. Our previous study demonstrated that a combination of TPA and ATRA (16) enhanced the anticancer activity of TPA. The present study demonstrates that low concentrations of gemcitabine in combination with TPA synergistically inhibit the growth and increase apoptosis in Panc-1 pancreatic cancer cells. These results indicate that the anticancer activity of gemcitabine may be increased while the toxic side-effects of gemcitabine may be reduced when a low dose is used in combination with TPA.

The mechanisms for the synergistic effect of TPA and gemcitabine on pancreatic cancer Panc-1 cells are not yet clear. 
TPA is known to activate protein kinase $\mathrm{C}$ (PKC) leading to the activation of JNK and apoptosis in several experimental systems $(25,39-42)$. In the present study, we found that TPA strongly activated JNK in Panc- 1 cells, and that the addition of a selective inhibitor of JNK partially abrogated the effect of TPA on growth inhibition and apoptosis stimulation. These results suggest that JNK activation is required for TPA-induced growth inhibition and apoptosis stimulation in cultured Panc-1 cells. The main action of gemcitabine is thought to be the competitive incorporation of gemcitabine diphosphate and triphosphate into DNA, after which DNA polymerase is able to add only one more nucleotide before DNA fragmentation and cell death occur $(43,44)$. This so-called 'masked chain termination' prevents exonuclease recognition and the excision of gemcitabine. Gemcitabine induces an S-phase arrest $(45,46)$ and stimulates apoptosis in cancer cells $(47,48)$. The activation of JNK is required for gemcitabine-induced apoptosis in human lung cancer cells (49). Gemcitabine alone or in combination with other agents has been shown to induce the activation of JNK in pancreatic cancer cells $(50,51)$. In the present study, we found that the treatment of Panc-1 cells with a low dose of gemcitabine resulted in a small increase in the level of phosphorylated-JNK. A combination of low doses of TPA and gemcitabine further increased the level of phosphorylated JNK in the cells. Moreover, we found that the addition of a selective JNK inhibitor partially abrogated the stimulatory effect of TPA in combination with gemcitabine on apoptosis in Panc-1 cells. These results suggest that apoptosis in Panc-1 cells induced by TPA in combination with gemcitabine is at least partially mediated by the activation of JNK.

In conclusion, in the present study, we show that TPA in combination with gemcitabine synergistically inhibits growth and induces apoptosis in Panc-1 human pancreatic cancer cells. The concentrations of TPA and gemcitabine required for these effects are clinically achievable. In addition, we found that the treatment of $\mathrm{NCr}$ nude mice with a combination of TPA and gemcitabine inhibited the growth of Panc-1 tumor xenografts. Clinical studies with TPA in combination with gemcitabine on patients with pancreatic cancer are warranted in order to confirm our results.

\section{Acknowledgements}

The present study was supported by departmental funds from the Department of Chemical Biology in the Ernest Mario School of Pharmacy at Rutgers University. The authors thank Ms. Annette Dionisio for her excellent assistance in the preparation of this manuscript.

\section{References}

1. Zavoral M, Minarikova P, Zavada F, Salek C and Minarik M: Molecular biology of pancreatic cancer. World J Gastroenterol 17: 2897-2908, 2011

2. Siegel R, Ward E, Brawley O and Jemal A: Cancer statistics, 2011: the impact of eliminating socioeconomic and racial disparities on premature cancer deaths. CA Cancer J Clin 61: 212-236, 2011.

3. Li D, Xie K, Wolff R and Abbruzzese JL: Pancreatic cancer. Lancet 363: 1049-1057, 2004.

4. Sultana A, Tudur Smith C, Cunningham D, Starling N, Neoptolemos JP and Ghaneh P: Meta-analyses of chemotherapy for locally advanced and metastatic pancreatic cancer: results of secondary end points analyses. Br J Cancer 99: 6-13, 2008.
5. Zalatnai A: Pancreatic cancer - a continuing challenge in oncology. Pathol Oncol Res 9: 252-263, 2003.

6. Ahrendt SA and Pitt HA: Surgical management of pancreatic cancer. Oncology 16: 725-734, 2002.

7. Wray CJ, Ahmad SA, Matthews JB and Lowy AM: Surgery for pancreatic cancer: recent controversies and current practice. Gastroenterol 128: 1626-1641, 2005.

8. Hilbig A and Oettle H: Gemcitabine in the treatment of metastatic pancreatic cancer. Expert Rev Anticancer Ther 8: 511-523, 2008.

9. Toschi L, Finocchiaro G, Bartolini S, Gioia V and Cappuzzo F: Role of gemcitabine in cancer therapy. Future Oncol 1: 7-17, 2005.

10. Burris HA III, Moore MJ, Andersen J, Green MR, Rothenberg ML, Modiano MR, Cripps MC, Portenoy RK, Storniolo AM, Tarassoff P, Nelson R, Dorr FA, Stephens CD and von Hoff DD: Improvements in survival and clinical benefit with as first-line therapy for patients with advanced pancreas cancer: a randomized trial. J Clin Oncol 15: 2403-2413, 1997.

11. Han ZT, Zhu XX, Yang RY, Sun JZ, Tian GF, Liu XJ, Cao GS, Newmark HL, Conney AH and Chang RL: Effect of intravenous infusions of 12-0-tetradecanoyl-phorbol-13-acetate (TPA) in patients with myelocytic leukemia: Preliminary studies on therapeutic efficacy and toxicity Proc Natl Acad Sci USA 95: 5357-5361, 1998.

12. Strair RK, Schaar D, Goodell L, Aisner J, Chin KV, Eid J, Senzon R, Cui XX, Han ZT, Knox B, Rabson AB, Chang R and Conney A: Administration of a phorbol ester to patients with hematological malignancies: preliminary results from a phase I clinical trial of 12-O-tetradecanoylphorbol-13-acetate. Clin Cancer Res 8: 2512-2518, 2002.

13. Schaar D, Goodell L, Aisner J, Cui XX, Han ZT, Chang R, Martin J, Grospe S, Dudek L, Riley J, Manago J, Lin Y, Rubin EH, Conney A and Strair RK: A phase I clinical trial of 12- O-tetradecanoylphorbol-13-acetate for patients with relapsed/ refractory malignancies. Cancer Chemother Pharmacol 57: 789-795, 2006.

14. Zheng X, Chang RL, Cui XX, Kelly KA, Shih WJ, Lin Y, Strair R, Suh J, Han ZT, Rabson A and Conney AH: Synergistic effects of clinically achievable concentrations of 12-O-tetradecanoylphorbol-13-acetate in combination with all-trans retinoic acid, 1alpha,25-dihydroxyvitamin D3, and sodium butyrate on differentiation in HL-60 cells. Oncol Res 12: 419-427, 2000.

15. Hansson A, Marín YE, Suh J, Rabson AB, Chen S, Huberman E, Chang RL, Conney $\mathrm{AH}$ and Zheng X: Enhancement of TPA-induced growth inhibition and apoptosis in myeloid leukemia cells by BAY 11-7082, an NF- $\kappa$ B inhibitor. Int J Oncol 27: 941-948, 2005.

16. Avila GE, Zheng X, Cui XX, Ryan AD, Hansson A, Suh J, Rabson AB, Chang RL, Shih WJ, Lin Y, Crowell P, Lu YP, Lou YR and Conney AH: Inhibitory effects of 12-O-tetradecanoylphorbol-13-acetate alone or in combination with all-trans retinoic acid on the growth of cultured human pancreas cancer cells and pancreas tumor xenografts in immunodeficient mice. J Pharmacol Exp Ther 315: 170-187, 2005.

17. Bond JA, Gescher AJ, Verschoyle RD, Lemoine NR, Errington R, Wiltshire M, Smith PJ and Wynford-Thomas D: Cytotoxic action of phorbol esters on human pancreatic cancer cells. Int J Cancer 121: 1445-1454, 2007.

18. Salabat MR, Ding XZ, Flesche JB, Ujiki MB, Robin TP, Talamonti MS, Bell RH Jr and Adrian TE: On the mechanisms of 12-O-tetradecanoylphorbol-13-acetate-induced growth arrest in pancreatic cancer cells. Pancreas 33: 148-155, 2006.

19. Detjen KM, Brembeck FH, Welzel M, Kaiser A, Haller H, Wiedenmann B and Rosewicz S: Activation of protein kinase Calpha inhibits growth of pancreatic cancer cells via p21(cip)-mediated G(1) arrest. J Cell Sci 113: 3025-3035, 2000.

20. Ploszaj T, Motyl T, Orzechowski A, Zimowska W, Wareski P, Skierski J and Zwierzchowski L: Antiapoptotic action of prolactin is associated with up-regulation of $\mathrm{Bcl}-2$ and downregulation of Bax in HC11 mouse mammary epithelial cells. Apoptosis 3: 295-304, 1998.

21. Zheng X, Chang RL, Cui XX, Avila GE, Lee S, Lu YP, Lou YR, Shih WJ, Lin Y, Reuhl K, Newmark H, Rabson A and Conney AH: Inhibitory effect of 12-O-tetradecanoylphorbol13-acetate alone or in combination with all-trans-retinoic acid on the growth of LNCaP prostate tumors in immunodeficient mice. Cancer Res 64: 1811-1820, 2004. 
22. Zheng X, Cui XX, Huang MT, Liu Y, Shih WJ, Lin Y, Lu YP, Wagner GC and Conney AH: Inhibitory effect of voluntary running wheel exercise on the growth of human pancreatic Panc- 1 and prostate PC-3 xenograft tumors in immunodeficient mice. Oncol Rep 19: 1583-1588, 2008.

23. Zhao L, Wientjes MG and Au JL: Evaluation of combination chemotherapy: integration of nonlinear regression, curve shift, isobologram, and combination index analyses. Clin Cancer Res 10: 7994-8004, 2004.

24. Hsu JC: Comparisons: Theory and Methods. Chapman and Hall, New York, NY, 1996.

25. Zheng X, Chang RL, Cui XX, Avila GE, Hebbar V, Garzotto M, Shih WJ, Lin Y, Lu SE, Rabson AB, Kong AN and Conney AH: Effects of 12-O-tetradecanoylphorbol-13-acetate (TPA) in combination with paclitaxel (Taxol) on prostate cancer LNCaP cells cultured in vitro or grown as xenograft tumors in immunodeficient mice. Clin Cancer Res 12: 3444-3451, 2006.

26. Van Duuren BL: Tumor-promoting agents in two-stage carcinogenesis. Prog Exp Tumor Res 11: 31-68, 1969.

27. Hecker E: Structure-activity relationships in diterpene esters irritant and cocarcinogenic to mouse skin. In: Mechanisms of Tumor Promotion and Cocarcinogenesis. Slaga TJ, Sivak AJ and Boutwell RK (eds). Raven, New York, NY, pp11-49, 1978.

28. Huberman $E$ and Callaham MF: Induction of terminal differentiation in human promyelocytic leukemia cells by tumor-promoting agents. Proc Natl Acad Sci USA 76: 1293-1297, 1979.

29. Lotem J and Sachs L: Regulation of normal differentiation in mouse and human myeloid leukemic cells by phorbol esters and the mechanism of tumor promotion. Proc Natl Acad Sci USA 76: 5158-5162, 1979.

30. Rovera G, O'Brien TG and Diamond L: Induction of differentiation in human promyelocytic leukemia cells by tumor promoters Science 204: 868-870, 1979.

31. Cui XX, Chang RL, Zheng X, Woodward D, Strair R and Conney AH: A sensitive bioassay for measuring blood levels of 12-O-tetradecanoylphorbol-13-acetate (TPA) in patients: preliminary pharmacokinetic studies. Oncol Res 13: 169-174, 2002.

32. Voutsadakis IA: Molecular predictors of gemcitabine response in pancreatic cancer. World J Gastrointest Oncol 3: 153-164, 2011.

33. Greenhalf $\mathrm{W}$ and Thomas A: Combination therapy for the treatment of pancreatic cancer. Anticancer Agents Med Chem 11: 418-426, 2011

34. Berlin JD, Catalano P, Thomas JP, Kugler JW, Haller DG and Benson AB III: Phase III study of gemcitabine in combination with fluorouracil versus gemcitabine alone in patients with advanced pancreatic carcinoma: Eastern Cooperative Oncology Group trial E2297. J Clin Oncol 20: 3270-3275, 2002 .

35. Rocha Lima CM, Green MR, Rotche R, Miller WH Jr, Jeffrey GM, Cisar LA, Morganti A, Orlando N, Gruia G and Miller LL: Irinotecan plus gemcitabine results in no survival advantage compared with gemcitabine monotherapy in patients with locally advanced or metastatic pancreatic cancer despite increased tumor response rate. J Clin Oncol 22: 3776-3783, 2004.

36. Louvet C, Labianca R, Hammel P, Lledo G, Zampino MG, André T, Zaniboni A, Ducreux M, Aitini E, Taïeb J, Faroux R, Lepere C and de Gramont A; GERCOR; GISCAD: Gemcitabine in combination with oxaliplatin compared with gemcitabine alone in locally advanced or metastatic pancreatic cancer: results of a GERCOR and GISCAD phase III trial. J Clin Oncol 23: $3509-3516,2005$
37. Oettle H, Richards D, Ramanathan RK, van Laethem JL, Peeters M, Fuchs M, Zimmermann A, John W, von Hoff D, Arning M and Kindler HL: A phase III trial of pemetrexed plus gemcitabine versus gemcitabine in patients with unresectable or metastatic pancreatic cancer. Ann Oncol 16: 1639-1645, 2005.

38. Abou-Alfa GK, Letourneau R, Harker G, Modiano M, Hurwitz H, Tchekmedyian NS, Feit K, Ackerman J, de Jager RL, Eckhardt SG and O'Reilly EM: Randomized phase III study of exatecan and gemcitabine compared with gemcitabine alone in untreated advanced pancreatic cancer. J Clin Oncol 24: 4441-4447, 2006.

39. Kim YR, Byun HS, Jeon J, Choi BL, Park KA, Won M, Zhang T, Shin S, Lee H, Oh J and Hur GM: Apoptosis signal-regulating kinasel is inducible by protein kinase $C \delta$ and contributes to phorbol ester-mediated G1 phase arrest through persistent JNK activation. Cell Biochem Biophys 61: 199-207, 2011.

40. Engedal N, Korkmaz CG and Saatcioglu F: C-Jun N-terminal kinase is required for phorbol ester- and thapsigargin-induced apoptosis in the androgen responsive prostate cancer cell line LNCaP. Oncogene 21: 1017-1027, 2002.

41. Ikezoe T, Yang Y, Taguchi $\mathrm{H}$ and Koeffler HP: JNK interacting protein 1 (JIP-1) protects LNCaP prostate cancer cells from growth arrest and apoptosis mediated by 12-0-tetradecanoylphorbol13-acetate (TPA). Br J Cancer 90: 2017-2024, 2004.

42. Tahara E, Kadara H, Lacroix L, Lotan D and Lotan R: Activation of protein kinase $\mathrm{C}$ by phorbol 12-myristate 13-acetate suppresses the growth of lung cancer cells through KLF6 induction. Cancer Biol Ther 8: 801-807, 2009

43. Huang P, Chubb S, Hertel LW, Grindey GB and Plunkett W: Action of 2',2'-difluorodeoxycytidine on DNA synthesis. Cancer Res 51: 6110-6117, 1991.

44. Ruiz van Haperen VW, Veerman G, Vermorken JB and Peters GJ: 2',2'-Difluoro-deoxycytidine (gemcitabine) incorporation into RNA and DNA of tumour cell lines. Biochem Pharmacol 46: 762-766, 1993.

45. Tolis C, Peters GJ, Ferreira CG, Pinedo HM and Giaccone G: Cell cycle disturbances and apoptosis induced by topotecan and gemcitabine on human lung cancer cell lines. Eur J Cancer 35: 796-807, 1999.

46. Pauwels B, Korst AE, Pattyn GG, Lambrechts HA, van Bockstaele DR, Vermeulen K, Lenjou M, de Pooter CM, Vermorken JB and Lardon F: Cell cycle effect of gemcitabine and its role in the radiosensitizing mechanism in vitro. Int J Radiat Oncol Biol Phys 57: 1075-1083, 2003.

47. Bouffard DY and Momparler RL: Comparison of the induction of apoptosis in human leukemic cell lines by difluorodeoxycytidine (gemcitabine) and cytosine arabinoside. Leuk Res 19: 849-856, 1995.

48. Ferreira CG, Tolis C, Span SW, Peters GJ, van Lopik T, Kummer AJ, Pinedo HM and Giaccone G: Drug-induced apoptosis in lung cancer cells is not mediated by the Fas/FasL (CD95/APO1) signaling pathway. Clin Cancer Res 6: 203-212, 2000.

49. Teraishi F, Zhang L, Guo W, Dong F, Davis JJ, Lin A and Fang B: Activation of c-Jun NH2-terminal kinase is required for gemcitabine's cytotoxic effect in human lung cancer H1299 cells. FEBS Lett 579: 6681-6687, 2005.

50. Osada S, Tomita H, Tanaka Y, Tokuyama Y, Tanaka H, Sakashita F and Takahashi T: The utility of vitamin K3 (menadione) against pancreatic cancer. Anticancer Res 28: 45-50, 2008.

51. Kreutzer JN, Ruzzene M and Guerra B: Enhancing chemosensitivity to gemcitabine via RNA interference targeting the catalytic subunits of protein kinase CK2 in human pancreatic cancer cells. BMC Cancer 10: 440, 2010. 